\title{
Badanie połączeń zgrzewanych blach stalowych metodą ultradźwiękową
}

\section{Inspection of welded joints of steel plate by ultrasonic method}

\section{Streszczenie}

W artykule przedstawiono sposób prowadzenia oraz wyniki badań - ultradźwiękowych i właściwości mechanicznych - blach zgrzewanych punktowo. Weryfikacji poddano połączenia blach stalowych o grubości $2,0 \mathrm{~mm}$. Ocenę nieniszczącą zrealizowano za pomocą podłużnej fali ultradźwiękowej o częstotliwości $20 \mathrm{MHz}$ oraz defektoskopu z możliwością zapisu uzyskanego sygnału z obszaru połączenia. Szacowaną na podstawie badań ultradźwiękowych jakość połączeń zweryfikowano podczas prób rozrywania. Otrzymane wyniki dla określonego połączenia blach z badań zarówno niszczących, jak i nieniszczących pozwoliły na oszacowanie procentowej skuteczności metody ultradźwiękowej oraz określenie jej przydatności do badań zgrzein punktowych blach.

Słowa kluczowe: blacha, zgrzewanie, ultradźwięki
Abstract

In the article are presented method and results of ultrasonic and mechanical research of spot-welded plates. Verification was conducted on steel plates with thickness of $2,0 \mathrm{~mm}$. The non-destructive evaluation was carried out using ultrasonic longitudinal waves with a frequency of $20 \mathrm{MHz}$ and a flaw detector with the ability to record the signal from connection area. Estimated on the basis of ultrasonic testing, joints quality was verified during the destructive test. The results obtained for combination of test plates of destructive and non-destructive testing allowed to estimate the rate and efficiency of the ultrasonic method to determine its suitability for testing of spot welds.

Key words: plate, spot welding, ultrasonic testing

\section{Wstęp}

Wśród różnych metod zgrzewania materiałów szczególne znaczenie ma zgrzewanie gazowe, szamotowe i przede wszystkim elektryczne. Ostatni z wymienionych sposobów zgrzewania znajduje szerokie zastosowanie w budowie maszyn i pojazdów samochodowych. Szczególnie zgrzewanie punktowe jest powszechnie wykorzystywane w procesie budowy zarówno elementów karoserii pojazdów, jak i komponentów nośnych wyposażenia wnętrza samochodu [1, 2].

Stosowanie połączeń zgrzewanych punktowo wymaga opracowania metod kontroli ich jakości w celu wykluczenia już na etapie produkcji wadliwie wykonanych zgrzein. Jedną $z$ metod stosowanych $w$ przemyśle są badania ultradźwiękowe. Polegają one na wygenerowaniu wiązki fali o wysokiej częstotliwości (np. $20 \mathrm{MHz}$ ), przepuszczeniu jej przez obszar złącza, a następnie interpretacji otrzymanego sygnału.

W nowoczesnych systemach produkcji badania ultradźwiękowe są prowadzone $w$ trybie on-line podczas procesu powstawania zgrzeiny. $\mathrm{W}$ takim przypadku sygnał ultradźwiękowy odbierany z obszaru złącza wykorzystywany jest do sterowania procesem zgrzewania. Dzięki takiemu rozwiązaniu uzyskuje się optymalne pa-

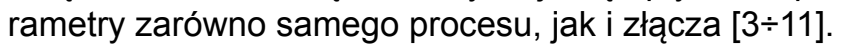

Pomimo dostępności tych systemów, w większości zakładów produkcyjnych wykorzystuje się pomiary wykonywane dopiero po zgrzaniu elementów. Taki wybór determinowany jest przez względy ekonomiczne.

W literaturze, np. [3, 9, 11], zazwyczaj w sposób ogólny przedstawiane są możliwości wykorzystania metody ultradźwiękowej w badaniach połączeń zgrzewanych blach stosowanych w przemyśle samochodowym. Techniczne możliwości metody ultradźwiękowej, spro-

Dr inż. Jakub Kowalczyk, mgr inż. Dariusz Ulbrich, dr inż. Ryszard Mańczak - Politechnika Poznańska. Autor korespondencyjny/Corresponding author: jakub.kowalczyk@put.poznan.pl 
wadzające się do wykrywania defektów w połączeniu zgrzewanym, takich jak: brak połączenia, przyklejenie, zbyt mały wymiar jądra zgrzeiny, zostały wskazane w [12]. W innych pracach przedstawiono nowoczesne systemy kontroli jakości zgrzein oparte na sieciach neuronowych, logice rozmytej bądź też badaniach ultradźwiękowych [4, 5, 7]. W dostępnej literaturze nie napotkano prac przedstawiających eksperymentalną weryfikację skuteczności metody ultradźwiękowej.

Głównym celem prowadzonych pomiarów, których rezultaty przedstawiono w tym artykule, było eksperymentalne sprawdzenie skuteczności metody ultradźwiękowej do oceny połączeń zgrzewanych blach stosowanych w produkcji pojazdów samochodowych.

\section{Przebieg badań}

Badaniami ultradźwiękowymi objęto połączenia zgrzewane dwóch blach o grubości 2,0 mm. Kolejne etapy realizacji eksperymentu przedstawiono na rysunku 1.

W pierwszym etapie eksperymentu wykonano połączenia zgrzewane elektrodami stożkowymi o średnicy $4 \mathrm{~mm}$. Przygotowane zgrzeiny ponumerowano, a następnie poddano badaniom ultradźwiękowym, które polegały na wygenerowaniu wiązki fali i przepuszczeniu jej przez obszar połączenia zgrzewanego. Na podstawie

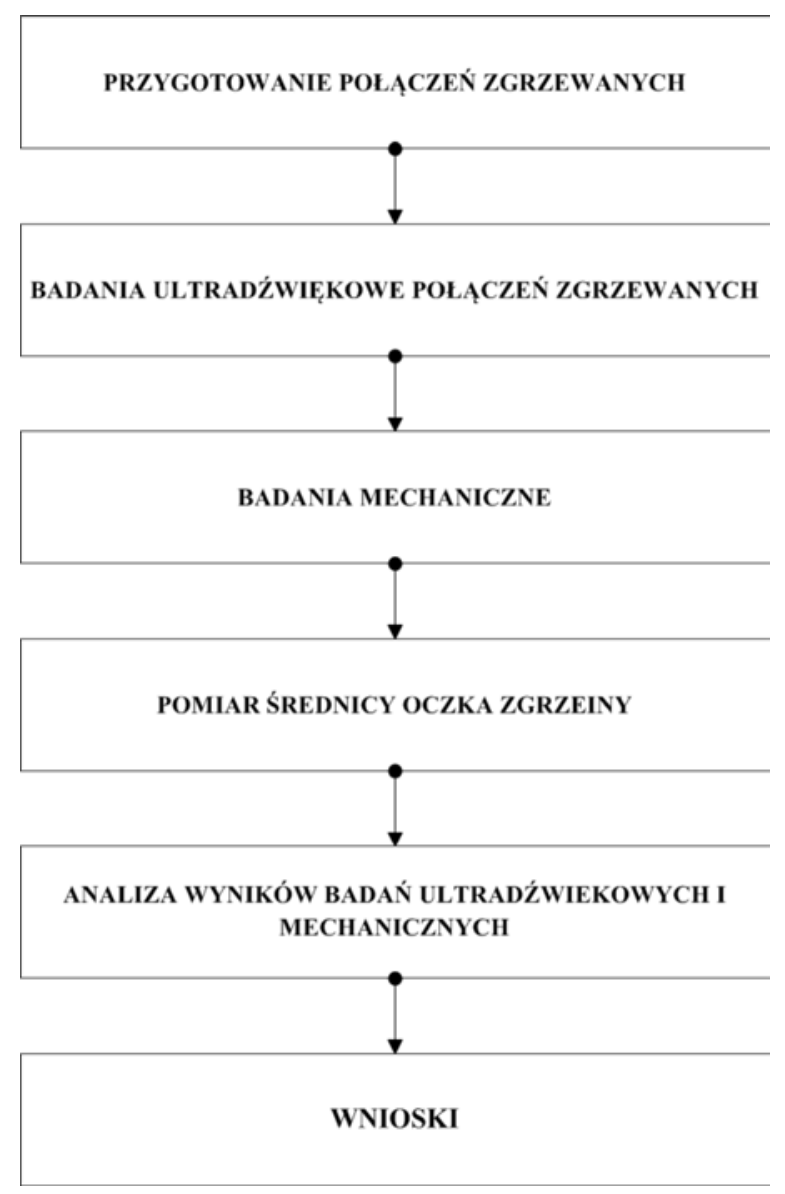

Rys. 1. Schemat realizacji zadania badawczego

Fig. 1. Scheme of research task uzyskanych sygnałów ultradźwiękowych podejmowano decyzję o jakości połączenia zgrzewanego, kierując się wytycznymi zawartymi w [12]. W kolejnym etapie przeprowadzono mechaniczną weryfikację jakości połączeń, poddając je rozrywaniu. Po rozerwaniu dokonano pomiarów średnicy jądra zgrzeiny w dwóch prostopadłych kierunkach, a ich średnią arytmetyczną przyjęto jako wynik końcowy.

\section{Wyniki badań i wnioski}

Wyniki badań ultradźwiękowych i mechanicznych połączeń zgrzewanych blach zawarto w tablicy. Zamieszczono w niej informację o parametrach i rezultatach pomiaru połączeń falą ultradźwiękową oraz dane o wymiarach jądra zgrzeiny i zgodności rezultatów badań ultradźwiękowych i mechanicznych.

Analizując wyniki badań ultradźwiękowych można stwierdzić, że większość połączeń została wykonana prawidłowo, a jedna zgrzeina (nr 15) została zakwalifikowana jako niespełniająca wymagań, ponieważ jej ją-

Tablica. Wyniki badań ultradźwiękowych i mechanicznych połączeń zgrzewanych

Table. Results of ultrasonic and mechanical tests of spot welds

\begin{tabular}{|c|c|c|c|c|}
\hline 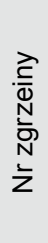 & 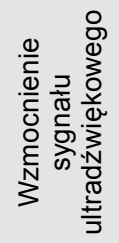 & 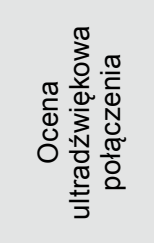 & 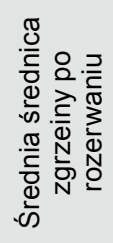 & 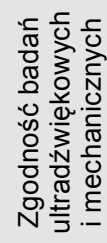 \\
\hline 1 & 68 & poprawne & 8,32 & tak \\
\hline 2 & 68 & poprawne & 6,63 & tak \\
\hline 3 & 70 & poprawne & 6,94 & tak \\
\hline 4 & 70 & poprawne & 6,69 & tak \\
\hline 5 & 70 & poprawne & 6,87 & tak \\
\hline 6 & 70 & poprawne & 6,89 & tak \\
\hline 7 & 70 & poprawne & 6,35 & tak \\
\hline 8 & 70 & poprawne & 6,88 & tak \\
\hline 9 & 70 & poprawne & 6,56 & tak \\
\hline 10 & 70 & poprawne & 5,25 & tak \\
\hline 11 & 70 & poprawne & 6,93 & tak \\
\hline 12 & 70 & poprawne & 5,51 & tak \\
\hline 13 & 70 & poprawne & 6,61 & tak \\
\hline 14 & 70 & poprawne & 7,47 & tak \\
\hline 15 & 70 & wadliwe & 3,48 & tak \\
\hline 16 & 70 & poprawne & 6,47 & tak \\
\hline 17 & 70 & poprawne & 5,95 & tak \\
\hline 18 & 74 & poprawne & 6,37 & tak \\
\hline 19 & 70 & poprawne & 7,07 & tak \\
\hline 20 & 68 & poprawne & 6,51 & tak \\
\hline
\end{tabular}


dro miało zbyt małą średnicę. Głowica ultradźwiękowa została tak dobrana, aby średnica jej wiązki w obszarze zgrzeiny była dostosowana do wymaganej minimalnej średnicy jądra zgrzeiny.

W przypadku właściwie wykonanego połączenia fala ultradźwiękowa w całości odbija się od dna zgrzeiny, co schematycznie pokazano na rysunku 2 a, a na rysunku 3 przedstawiono widok takiego sygnału uzyskanego podczas pomiarów. Gdy soczewka jądra ma zbyt małą średnicę, wówczas część wiązki fali odbija się od granicy połączenia blach (rys. 2b) i powstają na ekranie aparatu ultradźwiękowego dodatkowe sygnały zwane międzyechami, które na rysunku 4 wskazano prostokątnymi ramkami.
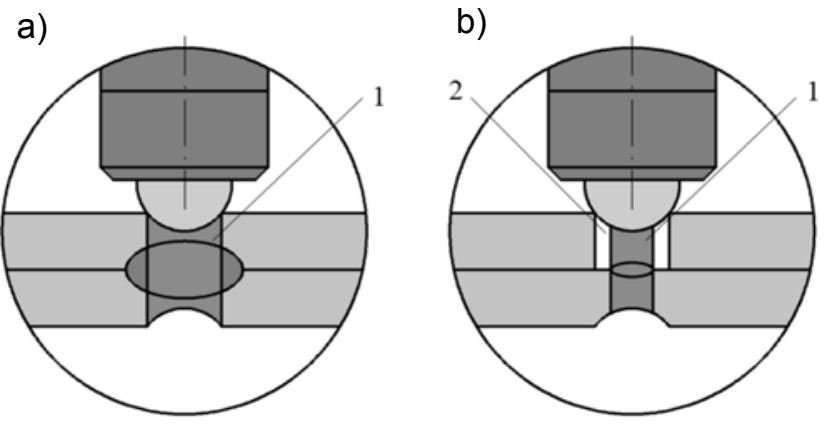

Rys. 2. Schemat badania ultradźwiękowego: a) soczewka zgrzeiny odpowiedniej wielkości, b) za mała soczewka zgrzeiny; 1 - fala odbita od dna próbki, 2 - fala odbita od pierwszej blachy

Fig. 2. Diagram of ultrasonic test: a) nugget of spot weld right size, b) for a small nugget of spot weld; 1 - ultrasonic wave reflected from the bottom of the sample, 2 - ultrasonic wave reflected from the first steel sheet

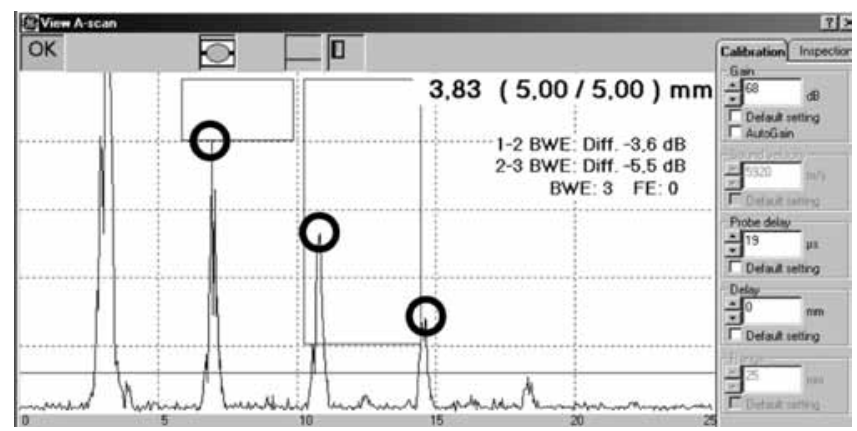

Rys. 3. Widok ekranu defektoskopu dla poprawnie wykonanego połaczenia zgrzewanego

Fig. 3. View of ultrasonic signal for good spot weld received on a screen of flaw detector

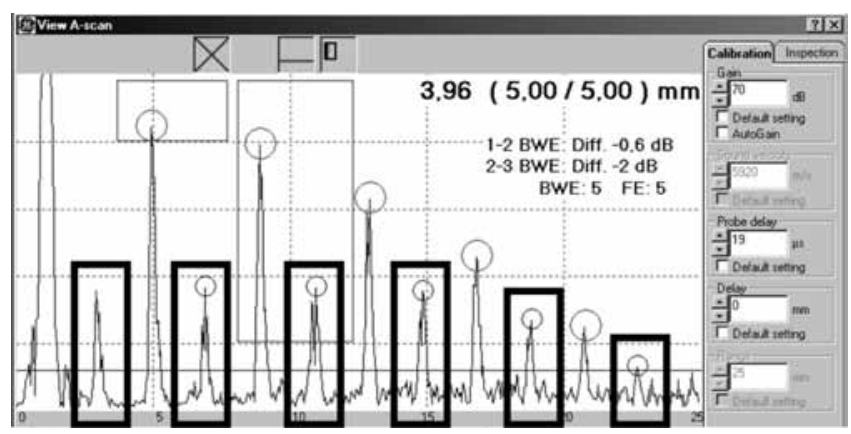

Rys. 4. Widok ekranu defektoskopu dla wadliwie wykonanego połączenia (15) - mała soczewka zgrzeiny

Fig. 4. View of ultrasonic signal for bad spot weld received on a screen of flaw detector (15) - small nugget

Wyniki wykonanych mechanicznych badań rozrywających potwierdziły, że dla 95\% połączeń średnica oczka zgrzeiny jest większa od wymaganej. Widok zgrzein po rozerwaniu pokazano na rysunku 5. Zaznaczono na nim połączenie wykonane właściwie i obszar zgrzeiny o średnicy oczka mniejszej niż wymagana. a)

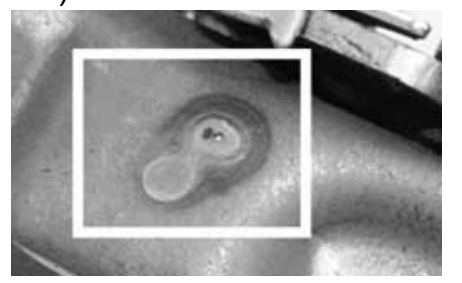

b)

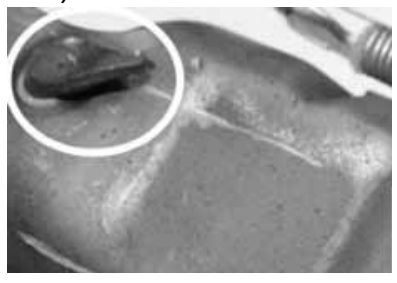

Rys. 5. Element po rozerwaniu połączeń zgrzewanych: a) kwadrat - obszar wadliwie wykonanej zgrzeiny, b) koło - obszar właściwie wykonanego połączenia

Fig. 5. View of part after destruction process of spot welds: a) square - area of defectively made spot weld, b) circle - areas of correctly made spot welds

Na podstawie wykonanych badań można sformułować następujące wnioski:

- metoda ultradźwiękowa umożliwia badanie połączeń zgrzewanych blach stalowych bez ingerencji w strukturę zgrzeiny, co, w przypadku pozytywnego wyniku badania, jest podstawą do skierowania elementu do dalszego etapu produkcji,

- otrzymany sygnał ultradźwiękowy z obszaru połączenia zgrzewanego świadczy o jego poprawnym wykonaniu lub występowaniu ewentualnych wad, jak np. za mała średnica jądra zgrzeiny.

\section{Podsumowanie}

Podczas eksperymentu przeprowadzono pomiary ultradźwiękowe dla połączeń zgrzewanych blach stalowych o grubości 2,0 mm. Badania nieniszczące wykazały w przypadku jednej zgrzeiny zbyt małą średnicę, co zostało potwierdzone po rozerwaniu połączenia. Weryfikacja metody ultradźwiękowej potwierdziła możliwość jej zastosowania do nieniszczącej oceny zgrzein na etapie procesu produkcyjnego, co umożliwia eliminację wadliwie wykonanych połączeń, wpływa na zwiększenie jakości produkowanych wyrobów oraz pozwala na obniżenie kosztów kontroli jakości w zakładach produkcyjnych. 
Rozpatrując otrzymane wyniki oraz przydatność metody ultradźwiękowej do oceny połączeń zgrzewanych, należy pamiętać, że badaniu poddano tylko część połączeń dla kombinacji blach o równej grubości. Kolejnym krokiem jest planowane wykonanie pomiarów dla łączonych blach o różnej grubości.
Porównując wartości otrzymane dla próbki rzeczywistej z wartościami dla elementu modelowanego wg wytycznych IIW można stwierdzić, że naprężenia w rzeczywistej konstrukcji są wyższe oraz większa objętość złącza narażona jest na działanie podwyższonego (większego od nominalnego) naprężenia.

\section{Literatura}

[1] Klimpel A.: Spawanie, Zgrzewanie i Cięcie Metali. Wydawnictwa Naukowo-Techniczne. Warszawa 2006.

[2] Papkala H.: Zgrzewanie Oporowe Metali. Wydawnictwo KaBe. Krosno 2003.

[3] Buckley J., Servent R.: Improvements in Ultrasonic Inspection of Resistance Spot Welds. The 2nd International Conference on Technical Inspection and NDT (TINDT 2008). October 2008, Teheran, Iran.

[4] Maev R., Chertov A., Regalado W., Karloff A., Lichaa P., Phan T.: Real Time Ultrasonic System for Resistance Spot Weld Inspection. Integration in Assembly Line. 4th International Candu In-service inspection and NDT in Canada. 18-21 June 2012, Toronto, Canada.

[5] Chertov A., Maev R. Gr.: Real-Time Ultrasonic Evaluation of the Aluminium Resistance Spot Welding Process. 4th International Candu In-service inspection and NDT in Canada. 18-21 June 2012, Toronto, Canada.

[6] Vural M., Akkus A.: The Ultrasonic Testing of the Spot WeIded Different Steel Sheets. Journal of Achievements in Materials and Manufacturing Engineering. Vol. 18, September - October 2006
[7] Ambroziak A., Koralewicz Z., Korzeniowski M., Kustroń P.: Metody Kontroli Jakości Zgrzein Punktowych w Czasie Rzeczywistym. Eksploatacja i Niezawodność. 2/2005, s. 61 66 .

[8] Wylie N., Wylie S.R., Cullen J.D., Al.-Shamma'a A.I.: Ultrasonic Non- Destructive Evaluation for Spot Welding in the

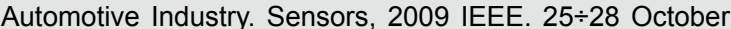
2009 , s. $1518 \div 1523$.

[9] Athi. N., Cullen J.D., Shaw A., Al.-Shamma'a A.I.: Online Monitoring for the Quality of Spot Welding. IEEE International Conference on Mechatronics and Automation. 9-12 August 2009, China, s. 2495 2499 .

[10] Vogt G., Rieger D., Kohler C.: Inline - Process and Quality Control of Spotwelds of Car Bodies - Ultrasonic Sensors Integrated in Resistance Welding Electrodes. Poster 26. ECNDT 2006.

[11] Kaminski R.: Ultrasonic Testing of Spot Welded Joints on Coated Steel Sheets and Optimization of Welding Parameters. Krautkramer. Spotweldtesting.com, 20.10.2013.

[12] Roye W.: Ultrasonic Testing of Spot Welds in The Automotive Industry. Krautkrämer, SD, 298 (11/99).

\section{ARTYKUKY ARCHIWALNE PRZEGLĄDU SPAWALNICTWA}

\section{Cena}

Cena 1 artykułu z numeru archiwalnego w wersji elektronicznej: 21 zł (w tym 5\% VAT)

W celu zamówienia artykułu należy wypełnić formularz zamieszczony obok i przesłać go w formie skanu wraz $z$ potwierdzeniem wpłaty na adres:

$$
\text { pspaw@ps.pl }
$$

Wpłaty należy dokonać na rachunek bankowy: Bank BPH S.A. Oddział w Warszawie 45106000760000320000431836

\section{Artykuły wysyłane są drogą elektroniczną} w ciągu 2 dni od otrzymania zamówienia.

\section{REDAKCJA - Przegląd Spawalnictwa AW SIMP}

ul. Świętokrzyska 14a, 00-050 Warszawa

tel.: 2282725 42, faks: 223361479

\section{Zamawiam artykuły:}

Nr zeszytu: .........., rok ............., strony ....................
Nr zeszytu: .........., rok ............, strony ....................
Nr zeszytu: ..........., rok ............, strony .....................

Adres e-mail

Imię i nazwisko

Firma

Adres

NIP

Kontakt do osoby zamawiającej:

Oświadczam, że jestem podatnikiem VAT i upoważniam firmę do wystawienia faktury bez podpisu 